\title{
Application of Problem Solving Theory by Siegler and Alibali in Early Detection of Cerebral Palsy Childern
}

\author{
Eustalia Wigunawati
}

\author{
Guidance and Counseling Study Program, Faculty of Teacher Training and Education \\ Universitas Kristen Indonesia \\ Corresponding Email: eustalia.wigunawati@uki.ac.id
}

\begin{abstract}
Children with Cerebral Palsy disorders have problems with muscle weakness, stiffness, awkwardness, slowness, and difficulty with balance. Cerebral palsy children need help from others in their movements and daily activities. However, not always the parents or the people around him will continue to accompany the child throughout his life. The question is to what extent do parents know the problem-solving abilities and independence of the cerebral palsy children? how do parents make early detection of children with cerebral palsy problem solving so that parents can help children in optimizing and more independent in carrying out daily activities by minimizing their dependence on parents or people around them, so that cerebral palsy children are able to function as part of community members in general with more optimal in accordance with the capacity they have. Siegler and Alibali (2005) in his book "The Children's Thingking" provide an explanation of the child's ability in general to do problem solving according to age and stage of development. The writing of this article is based on a literature study from several literatures with a content analysis study. The discussion in this article problem solving proposed by Siegler and Alibali which was then applied to children with cerebral palsy. By knowing the problem solving abilities possessed by children with cerebral palsy, the hope is that they can optimize their children's abilities to be more independent in carrying out daily activities by minimizing their dependence on parents or people around them, so that the cerebral palsy children are able to function as part in general community members more optimally according to their capacity.
\end{abstract}

Keywords: cerebral palsy children, problem solving

\section{INTRODUCTION}

Giving birth normally is every mother's dream (Janjic et al., 2013; Regan et al., 2019). The hope is that babies born are healthy babies and mothers also give birth, of course. But on the way, a mother's pregnancy does not always go well. Many disorders occur during pregnancy, most are dangerous and require emergency action (Cardwell, 2013; Katz and Beilin, 2015; Pearlstein, 2015). Pregnancy disorders can occur at any time, can be during a young pregnancy, or during advanced pregnancy, as well as in the moments before delivery. Disorders that occur during pregnancy and before delivery can be bad for the growth of the baby (ACOG, 2018; Cook et al., 1991; Rotich and Wolvaardt, 2017; Seridi and Beauquier-Maccotta, 2019). Babies can experience disorders, one of which is Cerebral Palsy. Monash Medical Centre says that the cause of Cerebral Palsy is different in every child, the problem is related to the brain. The brain in infants with Cerebral Palsy disorders does not grow in the right shape, so the child has a brain disability (Miller and Bachrach, 2008; Richards and Malouin, 2013; Shira Sender, 2019). Cerebral palsy disorders that occur early in pregnancy for example, if it shows that the mother is infected with rubella or cytomegalovirus (Hamprecht et al., 2001; Pass and Anderson, 2014).

According to some experts at the Royal Children's Hospital, in some children despite having gone through several detailed testing processes, the cause of Cerebral Palsy cannot be clearly known (Miller and Bachrach, 2008; Richards and Malouin, 2013; Shira Sender, 2019). According to the Royal Children's Hospital (Colver et al., 2014; Does et al., 2009), The Gross Motor Fuction Classification System (GMFCS) is a method that describes various gross motor functions in children with Cerebral Palsy disorders.

However cerebral palsy children must be able to regulate themselves when faced with everyday problems. According to Santrock (2008), cognition refers to mental activities about how information enters the mind, is stored and transformed and called back and used in complex activities such as thinking. Piaget states that 
during its development, humans experience changes in the structure of thinking, which is increasingly organized (Santrock, 2010).

Child's ability in general to do problem solving according to age and stage of development (Atance, 2008; Kuhn, 1989; Papert, 1972). The author feels that this can be a reference for parents in conducting early detection for children with cerebral palsy.

One important type of cognitive processing that occurs during learning is problem solving. Problem solving refers to people's efforts to achieve goals because they do not have automatic solutions (Ing, 2012; Schunk, 2012). Problem solving is a mental process that is used for problem solving based on cognitive abilities to gain knowledge, thinking skills, and behavior to be understood (Santrock, 2010).

There are several aspects of problem solving, including (Atance, 2008; Kuhn, 1989; Papert, 1972):

a. Task analysis, is the process of analyzing a task (problem) that must be solved. Here is the process of identifying problems that are very useful for solving problems later.

b. Encoding, in which there is identification of critical information in a situation and use it to build an internal representation of the situation.

c. Mental model, a kind of internal symbol that is represented by external reality.

d. Domain-general and domain-specific knowledge, the process of solving problems varies according to what situation it can be applied to.

e. Developmental differences, the key to unlocking children's ability to solve problems is to simplify problems by eliminating unrelated things in a problem.

f. Processes of change, in this aspect, we will discuss how changes in the problem solving process occur.

There are several important processes in problem solving, including (Rittle-Johnson et al., 2001; Robert S Siegler, 2016):

a. Planning, is an arrangement of actions used to solve a problem. Plans involve elements of subgoals, how to achieve, and final goals. In children, the use of this aspect is not optimal, but children are able to use two heuristic strategies that are commonly used by adults in problem solving, namely:

1) Means-Ends Analysis.

The respondent's job is to move the three rings to the rightmost peg with two simple rules, namely: (1) Move one ring at a time (one step), (2) The ring must be moved to the right hand peg from the largest to the smallest order (respondents are allowed to use the center peg as an introduction), and (3) There are several ways to solve problems in the Tower of Hanoi, from the simplest to the most complicated.

Table 1: Answer Key to the Means-Ends Analysis Test

\begin{tabular}{|c|c|}
\hline Age & Achievement of problem solving \\
\hline 1 year & $\begin{array}{c}\text { With the help of only being able to } \\
\text { move the ring without } \\
\text { understanding the rules in this } \\
\text { experiment }\end{array}$ \\
\hline 3-4 years & $\begin{array}{c}\text { Solve problems in the tower of } \\
\text { Hanoi with 2 steps (able to combine } \\
2 \text { rules) }\end{array}$ \\
\hline 4-5 years & $\begin{array}{c}\text { Able to solve 4 movements on the } \\
\text { tower of Hanoi }\end{array}$ \\
\hline 5-6 years & $\begin{array}{c}\text { Able to use 5-6 movements of the } \\
\text { Hanoi tower }\end{array}$ \\
\hline
\end{tabular}

2) Route Planning. One of the other heurastic methods in problem solving is to choose the most effective way to achieve goals. Children at the beginning of their development have the ability to use route planning strategies, according to Benson, Arehant in Siegler (2005) children at 1 year of age have been able to recognize the part of the house where toys are placed. The use of this strategy is getting better with age. Febricius's research in Siegler (2005) concluded that aged 4 to 5 years, children have been able to use goal planning well, while children aged 5-6 years identified several alternatives before starting work and were able to correct mistakes faster than children under 4 years. Gardner and Rogoff's research in Siegler (2005) revealed that children in the concrete operational phase have been able to plan several alternative goals, select the most effective alternatives and correct mistakes quickly.

Test: respondent is asked to recall memory about where the respondent used to store toys at home.

Table 2: Answer Key to the Route Planning Test

\begin{tabular}{|c|c|}
\hline Age & Achievement of problem solving \\
\hline 1-4 year & $\begin{array}{c}\text { able to recognize parts of the house } \\
\text { where to put toys }\end{array}$ \\
\hline 4-5 years & $\begin{array}{c}\text { children have been able to use goal } \\
\text { planning well }\end{array}$ \\
\hline $5-6$ years & $\begin{array}{l}\text { recognize several alternatives before } \\
\text { starting work and be able to correct } \\
\text { mistakes faster than children under } \\
\text { 4 years }\end{array}$ \\
\hline
\end{tabular}

b. Causal Inference, is a relationship or mutual influence of two problems. The aspect of cause and effect relationships puts problem solving as a bridge between cause and effect. The development of 
cognition in children begins when the child develops curiosity and starts the question "why". Siegler (2005) states that children's interest in the causal aspect begins to be observed in children aged 2 years by developing their curiosity in the sound of sirens in car toys or in clockwork.

Test: Respondents are given a video about a ball that moves because it is kicked. Respondents were asked to explain why the ball could move.

Table 3: Answer Key to The Causal Inference Test

\begin{tabular}{|c|c|}
\hline Age & Achievement of problem solving \\
\hline $0-2$ years & $\begin{array}{c}\text { It is not yet aware of a causal } \\
\text { relationship }\end{array}$ \\
\hline $2-3$ years & $\begin{array}{c}\text { It is still difficult to distinguish } \\
\text { between physical and psychological } \\
\text { causal relationships }\end{array}$ \\
\hline 3-7 years & $\begin{array}{c}\text { Children starting to understand this } \\
\text { causal relationship will try to use it } \\
\text { as a problem solving strategy }\end{array}$ \\
\hline $7-9$ years & $\begin{array}{c}\text { Able to categorize, separate, match } \\
\text { several objects according to the } \\
\text { categories they make themselves }\end{array}$ \\
\hline
\end{tabular}

c. Analogy, is a process of reasoning using a comparison of two different things by looking at the similarities of the two things being compared so that it can be used to solve problems.

Test: respondents are given a set of animal figure toys. Then respondents are asked to choose different animal figures but have the same nature.

Table 4: Answer Key to the Analogy Test

\begin{tabular}{|c|c|}
\hline Age & Achievement of problem solving \\
\hline 1 year & $\begin{array}{l}\text { Already have the ability to attent, } \\
\text { reach for toys in a few seconds, } \\
\text { began to be able to use analog with } \\
\text { a very similar atmosphere with the } \\
\text { help of parents }\end{array}$ \\
\hline 2 years & $\begin{array}{l}\text { Able to use a very simple analogy. } \\
\text { Usually still confused by analogy } \\
\text { with physical similarity }\end{array}$ \\
\hline 3 years & $\begin{array}{l}\text { Able to use several meaningful } \\
\text { analogies to solve problems }\end{array}$ \\
\hline 4-5 years & $\begin{array}{c}\text { able to use the analogy process and } \\
\text { use relevant aspects in problem } \\
\text { solving }\end{array}$ \\
\hline 5-6 years & Able to use analog well \\
\hline Middle children & $\begin{array}{l}\text { Able to use effective planning and } \\
\text { strategy in analog }\end{array}$ \\
\hline $\begin{array}{c}\text { Formal } \\
\text { operational }\end{array}$ & Consistently use analogies \\
\hline
\end{tabular}

d. Tool Use, Children in building problem solving skills often use problem solving tools, such as sticks, hooks, maps, language use, and the help of others. According to Mosier and Rogof in Siegler and Alibali (2005) that the tools that are used first by children in their early development (ages 6-13 months are mothers or caregivers), this can be seen from research that children will reach for toys with hand movements with the caregiver's help. As age develops, children are able to use inanimate objects as a tool for problem solving.

Test: Respondents are confronted with a photo of a toy rack where they usually keep their toys.

Table 5: Answer Key to the Tool Use Test

\begin{tabular}{|c|c|}
\hline Age & Achievement of problem solving \\
\hline 2,5 years & $\begin{array}{c}\text { Success at original location but } \\
\text { having difficulty at analogy location }\end{array}$ \\
\hline 3 years & $\begin{array}{c}\text { Successfully represented both } \\
\text { symbols in analog locations and in } \\
\text { actual locations }\end{array}$ \\
\hline
\end{tabular}

e. Scientific and logical reasoning

1) Scientific reasoning, Children are often equated with scientists.

2) Logical reasoning, Consider the following, the logic of a 4-year-old: "If it doesn't break when I drop it, it's a stone ... It doesn't break. Tests: respondents are given 2 statements that are deductive or inductive. For example:

- Deductive: people do not have hands $\rightarrow$ handicapped; A has no hands $\rightarrow$ Is A called a handicapped?

- Inductive: Doctors wear white coats; A wears a white coat $\rightarrow$ Is A doctor?

Table 6: Answer Key to the Scientific and Logical Test

\begin{tabular}{|c|c|}
\hline Age & Achievement of problem solving \\
\hline 5 years & $\begin{array}{c}\text { Already started to be able to solve } \\
\text { problems with simple logic methods } \\
\text { and also began to use alternative } \\
\text { strategies to solve their problems. }\end{array}$ \\
\hline
\end{tabular}

\section{METHOD}

The writing of this article is based on a literature study from several literatures with a content analysis study. The discussion in this article problem solving proposed by Siegler and Alibali which was then applied to children with cerebral palsy. 


\section{DISCUSSION}

In answering the question in this article about "how far do parents know the ability to solve problems and independence of children with cerebral palsy?", Then parents must detect early how much the ability of children with cerebral pasly to solve problems. So far there has been no discussion that explains the specific problem solving for children with cerebral palsy. However, what has been explained by Siegler and Alibali (2005) regarding children's problem solving abilities according to age and stage of development in general can be a reference for parents who have children with cerebral palsy. Problem solving abilities that can be demonstrated by children with cerebral palsy can be adjusted to the age of problem solving that has been described by Siegler and Alibali (2005). The important process of problem solving shown by Siegler and Alibali (2005) as explained earlier is as follows:

a. Planning, is an arrangement of actions used to solve a problem. Plans involve elements of subgoals, how to achieve, and final goals. In children, the use of this aspect is not optimal, but children are able to use two heuristic strategies that are commonly used by adults in problem solving, namely:

1) Means-Ends Analysis. A heuristic in which individuals identify goals, assess the current situation and evaluate what actions are needed to reduce the difference between the two conditions.

The respondent's job is to move the three rings to the rightmost peg with two simple rules, namely:

Move one ring at a time (one step)

- The ring must be moved to the right hand peg from the largest to the smallest order (respondents are allowed to use the center peg as an introduction)

- There are several ways to solve problems in the Tower of Hanoi, from the simplest to the most complicated.

Table 1: Answer Key to the Means-Ends Analysis Test

\begin{tabular}{|c|c|}
\hline Age & Achievement of problem solving \\
\hline 1 year & $\begin{array}{c}\text { With the help of only being able to } \\
\text { move the ring without } \\
\text { understanding the rules in this } \\
\text { experiment }\end{array}$ \\
\hline $3-4$ years & $\begin{array}{c}\text { Solve problems in the tower of } \\
\text { Hanoi with 2 steps (able to combine } \\
\text { 2 rules) }\end{array}$ \\
\hline 4-5 years & $\begin{array}{c}\text { Able to solve } 4 \text { movements on the } \\
\text { tower of Hanoi }\end{array}$ \\
\hline $5-6$ years & $\begin{array}{c}\text { Able to use 5-6 movements of the } \\
\text { Hanoi tower }\end{array}$ \\
\hline
\end{tabular}

2) Route Planning. One of the other heurastic methods in problem solving is to choose the most effective way to achieve goals. Children at the beginning of their development have the ability to use route planning strategies, according to Benson, Arehant in Siegler (2005) children at 1 year of age have been able to recognize the part of the house where toys are placed. The use of this strategy is getting better with age. Febricius's research in Siegler (2005) concluded that aged 4 to 5 years, children have been able to use goal planning well, while children aged 5-6 years identified several alternatives before starting work and were able to correct mistakes faster than children under 4 years . Gardner and Rogoff's research in Siegler (2005) revealed that children in the concrete operational phase have been able to plan several alternative goals, select the most effective alternatives and correct mistakes quickly.

Test: respondent is asked to recall memory about where the respondent used to store toys at home.

Table 2: Answer Key to the Route Planning Test

\begin{tabular}{|c|c|}
\hline Age & Achievement of problem solving \\
\hline $1-4$ year & $\begin{array}{c}\text { able to recognize parts of the house } \\
\text { where to put toys }\end{array}$ \\
\hline $4-5$ years & $\begin{array}{c}\text { children have been able to use goal } \\
\text { planning well }\end{array}$ \\
\hline $5-6$ years & $\begin{array}{l}\text { recognize several alternatives before } \\
\text { starting work and be able to correct } \\
\text { mistakes faster than children under } \\
\text { 4 years }\end{array}$ \\
\hline
\end{tabular}

b. Causal Inference, is a relationship or mutual influence of two problems. The aspect of cause and effect relationships puts problem solving as a bridge between cause and effect. The development of cognition in children begins when the child develops curiosity and starts the question "why". Siegler (2005) states that children's interest in the causal aspect begins to be observed in children aged 2 years by developing their curiosity in the sound of sirens in car toys or in clockwork.

Test: Respondents are given a video about a ball that moves because it is kicked. Respondents were asked to explain why the ball could move.

Table 3: Answer Key to the Causal Inference Test

\begin{tabular}{|c|c|}
\hline Age & Achievement of problem solving \\
\hline $0-2$ years & $\begin{array}{c}\text { It is not yet aware of a causal } \\
\text { relationship }\end{array}$ \\
\hline
\end{tabular}




\begin{tabular}{|c|c|}
\hline $2-3$ years & $\begin{array}{c}\text { It is still difficult to distinguish } \\
\text { between physical and psychological } \\
\text { causal relationships }\end{array}$ \\
\hline $3-7$ years & $\begin{array}{c}\text { Children starting to understand this } \\
\text { causal relationship will try to use it } \\
\text { as a problem solving strategy }\end{array}$ \\
\hline $7-9$ years & $\begin{array}{c}\text { Able to categorize, separate, match } \\
\text { several objects according to the } \\
\text { categories they make themselves }\end{array}$ \\
\hline
\end{tabular}

c. Analogy, is a process of reasoning using a comparison of two different things by looking at the similarities of the two things being compared.

Test: respondents are given a set of animal figure toys. Then respondents are asked to choose different animal figures but have the same nature.

Table 4: Answer Key to the Analogy Test

\begin{tabular}{|c|c|}
\hline Age & Achievement of problem solving \\
\hline 1 year & $\begin{array}{l}\text { Already have the ability to attent, } \\
\text { reach for toys in a few seconds, } \\
\text { began to be able to use analog with } \\
\text { a very similar atmosphere with the } \\
\text { help of parents }\end{array}$ \\
\hline 2 years & $\begin{array}{l}\text { Able to use a very simple analogy. } \\
\text { Usually still confused by analogy } \\
\text { with physical similarity }\end{array}$ \\
\hline 3 years & $\begin{array}{l}\text { Able to use several meaningful } \\
\text { analogies to solve problems }\end{array}$ \\
\hline $4-5$ years & $\begin{array}{l}\text { able to use the analogy process and } \\
\text { use relevant aspects in problem } \\
\text { solving }\end{array}$ \\
\hline $5-6$ years & Able to use analog well \\
\hline Middle children & $\begin{array}{l}\text { Able to use effective planning and } \\
\text { strategy in analog }\end{array}$ \\
\hline $\begin{array}{c}\text { Formal } \\
\text { operational }\end{array}$ & Consistently use analogies \\
\hline
\end{tabular}

d. Tool Use, Children in building problem solving skills often use problem solving tools, such as sticks, hooks, maps, language use, and the help of others. According to Mosier and Rogof in Siegler and Alibali (2005) that the tools that are used first by children in their early development (ages 6-13 months are mothers or caregivers), this can be seen from research that children will reach for toys with hand movements with the caregiver's help. Test: Respondents are confronted with a photo of a toy rack where they usually keep their toys.

Table 5: Answer Key to the Tool Use Test

\begin{tabular}{|c|c|}
\hline Age & Achievement of problem solving \\
\hline 2,5 years & $\begin{array}{c}\text { Success at original location but } \\
\text { having difficulty at analogy location }\end{array}$ \\
\hline
\end{tabular}

\begin{tabular}{|c|c|}
\hline 3 years & $\begin{array}{c}\text { Successfully represented both } \\
\text { symbols in analog locations and in } \\
\text { actual locations }\end{array}$ \\
\hline
\end{tabular}

e. Scientific and logical reasoning

1) Scientific reasoning, Children are often equated with scientists. Both of them are asking fundamental questions about the nature of the universe.

2) Logical reasoning, Consider the following, the logic of a 4-year-old: "If it doesn't break when I drop it, it's a stone ... It doesn't break.

Tests: respondents are given 2 statements that are deductive or inductive. For example:

- Deductive: people do not have hands $\rightarrow$ handicapped; A has no hands $\rightarrow$ Is A called a handicapped?

- Inductive: Doctors wear white coats; A wears a white coat $\rightarrow$ Is A a doctor?

Table 6: Answer Key to the Scientific and Logical Test

\begin{tabular}{|c|c|}
\hline Age & Achievement of problem solving \\
\hline 5 years & $\begin{array}{c}\text { Already started to be able to solve } \\
\text { problems with simple logic methods } \\
\text { and also began to use alternative } \\
\text { strategies to solve their problems. }\end{array}$ \\
\hline
\end{tabular}

By following the references described by Siegler and Alibali (2005), it will be recognized the extent of the problem solving ability of children with cerebral palsy.

\section{CONCLUSIONS}

Based on the explanation of problem solving in children presented by Siegler and Alibali (2005) it can be concluded that the child has the ability to solve problems in accordance with the tasks and stages of development. Although what Siegler and Alibali conveyed applies to children in general, but this explanation is very useful also for parents who want to know the problem solving abilities of their children who have cerebral palsy disorders. Parents can detect the extent of a child's cerebral palsy in problem solving abilities. By knowing the problem solving abilities possessed by children with cerebral palsy, the hope is that they can optimize their children's abilities to be more independent in carrying out daily activities by minimizing their dependence on parents or people around them, so that the cerebral palsy children are able to function as part in general community members more optimally according to their capacity. 


\section{REFERENCES}

[1] ACOG, 2018. Preeclampsia and High Blood Pressure During Pregnancy. Am. Coll. Obstet. Gynecol.

[2] Atance, C.M., 2008. Future thinking in young children. Curr. Dir. Psychol. Sci. https://doi.org/10.1111/j.14678721.2008.00593.x

[3] Cardwell, M.S., 2013. Eating disorders during pregnancy. Obstet. Gynecol. Surv. https://doi.org/10.1097/OGX.0b013e31828736b9

[4] Colver, A., Fairhurst, C., Pharoah, P.O.D., 2014. Cerebral palsy, in: The Lancet. https://doi.org/10.1016/S01406736(13)61835-8

[5] Cook, P.S., Petersen, R.C., Moore, D.T., 1991. Counseling women about childbearing and childrearing risks. J. Addict. Nurs. https://doi.org/10.3109/10884609109077637

[6] Does, W., Palsy, C., Causes, W., Palsy, C., 2009. Introduction to Cerebral Palsy. MyChild Without Limits.org.

[7] Hamprecht, K., Maschmann, J., Vochem, M., Dietz, K., Speer, C.P., Jahn, G., 2001. Epidemiology of transmission of cytomegalovirus from mother to preterm infant by breastfeeding. Lancet. https://doi.org/10.1016/S0140-6736(00)04043-5

[8] Ing, M., 2012. Learning theories, in: Theory and Practice of Curriculum Studies. https://doi.org/10.4324/9780203814840

[9] Janjic, V., Milovanovic, D., Ruzic-Zecevic, D., Loncar, D., Laban, O., Stepanovic, M., Varjacic, M., Obradovic, S., Djukic-Dejanovic, S., Jankovic, S., 2013. Zuclopenthixol decanoate in pregnancy: Successful outcomes in two consecutive off springs of the same mother. Vojnosanit. Pregl. Med. Pharm. J. Serbia. https://doi.org/10.2298/vsp120208005j

[10] Katz, D., Beilin, Y., 2015. Disorders of coagulation in pregnancy. Br. J. Anaesth. https://doi.org/10.1093/bja/aev374

[11] Kuhn, D., 1989. Children and Adults as Intuitive Scientists. Psychol. Rev. https://doi.org/10.1037/0033295X.96.4.674

[12] Miller, F., Bachrach, S.J., 2008. Cerebral palsy: A complete guide for caregiving, in: Cerebral Palsy: A Complete Guide for Caregiving.

[13] Papert, S., 1972. Teaching Children Thinking. Program. Learn. $\quad$ Educ. Technol. https://doi.org/10.1080/1355800720090503

[14] Pass, R.F., Anderson, B., 2014. Mother-to-child transmission of cytomegalovirus and prevention of congenital infection. J. Pediatric Infect. Dis. Soc. https://doi.org/10.1093/jpids/piu069

[15] Pearlstein, T., 2015. Depression during Pregnancy. Best Pract. Res. Clin. Obstet. Gynaecol. https://doi.org/10.1016/j.bpobgyn.2015.04.004

[16] Regan, F., Lees, C.C., Jones, B., Nicolaides, K.H., Wimalasundera, R.C., Mijovic, A., 2019. Prenatal Management of Pregnancies at Risk of Fetal Neonatal Alloimmune Thrombocytopenia (FNAIT): Scientific Impact Paper No. 61. BJOG An Int. J. Obstet. Gynaecol. https://doi.org/10.1111/1471-0528.15642

[17] Richards, C.L., Malouin, F., 2013. Cerebral palsy An Information Guide for Parents and Families, Handbook of clinical neurology. https://doi.org/10.1016/B978-0444-52891-9.00018-X

[18] Rittle-Johnson, B., Siegler, R.S., Alibali, M.W., 2001. Developing conceptual understanding and procedural skill in mathematics: An iterative process. J. Educ. Psychol. https://doi.org/10.1037/0022-0663.93.2.346

[19] Robert S Siegler, 2016. Continuity and Change in the Field of Cognitive Development and in the Perspectives of One Cognitive Developmentalist. Child Dev. Perspect. https://doi.org/10.1111/cdep.12173

[20] Rotich, E., Wolvaardt, L., 2017. A descriptive study of the health information needs of Kenyan women in the first 6 weeks postpartum. BMC Pregnancy Childbirth. https://doi.org/10.1186/s12884-017-1576-1

[21] Santrock, J.H., 2010. Educational Psychologyan. McGraw-Hill, New York.

[22] Schunk, D.H., 2012. Learning theories: An educational perspective, Reading.

[23] Seridi, H.B., Beauquier-Maccotta, B., 2019. Sleeping disorders in pregnancy and post-partum (review). Ann. Med. Psychol.

(Paris). https://doi.org/10.1016/j.amp.2017.05.020

[24] Shira Sender, J., 2019. Cerebral Palsy: A Complete Guide for Caregiving. J. Consum. Health Internet. https://doi.org/10.1080/15398285.2019.1582252 